堆 積 学 研 究, 49号, 23-39, 1999

J. Sed. Soc. Japan. No. 49，23-39，1999

\title{
新潟・長野県境富倉地域における中新〜鮮新統の堆積過程
}

\section{中村 稔彦*}

\section{Depositional processes of the Upper Miocene to Pliocene turbidites in the Tomikura area, located around the border of Niigata and Nagano Prefectures}

\author{
Toshihiko Nakamura*
}

\begin{abstract}
The turbidite of the Kamikozawa Formation in the Tomikura region was deposited in a NNE-SSW trending trough-basin at the west flank of the Tomikura Anticline and in a channel-like trough basin at the east flank differentiated by tectonic movement from latest Miocene to Pliocene time. In the eastern channel-like trough basin, andesite clasts were supplied laterally from the Kato Mountains, south of the Tomikura area, by tectonic uplift of basement rocks, and channel-fill deposits were developed. In the trough-like basin at the west flank, turbidite deposits were formed by sheet flow turbidity currents supplied longitudinally from the Minochi region southwest of the Tomikura region. The Tomikura region was a junction of a NNE-SSW trending trough continuous from the Minochi region to the Higashikubiki region and a channel-like trough connected from the Kato Mountains to the south.
\end{abstract}

Key words : turbidite, depositional process, Pliocene, Tomikura, Fossa Magna region

\section{1.はじめに}

北部フォッサ・マグナ地域は西南日本と東北日本 の会合部にあたり，後期新生代において複雑な地史 をたどってきた地域である。とくに長野県松本から 新潟平野にかけては沈降量が大きく, 数千メートル に達する新第三系, 第四系堆積物が発達している。 これらの堆積物のなかで, いわゆる「タービダイト」 と呼ばれる堆積物重力流によって堆積盆を埋積した 粗粒砕屑物が発達する層準は 2 層準ある。下位のも のは中期から後期中新世に発達した難波山層であ り，上位のものは中新世末から鮮新世に発達した椎 谷・浜忠層である。難波山層は遠藤・立石（1990）

受付：1998年11月24日 受理：1999年 3 月23日

$*$ 新潟県立川西高等学校

Kawanishi high school, 771-2, Ise-heizi, Kawanishi, Niigata 984-0131, Japan
によって報告された，Mutti \& Ricci-Lucchi（1972） によって提唱された海底扇状地モデルの堆積様式を 特徴とするタービダイトである。また，椎谷・浜忠 層は，高野（1990）によって報告された東䅡城地域 田麦川層の例があり，この時代のタービダイトは， NE-SW 方向に浅化・分化したトラフ状の堆積盆を 埋積する堆積様式を特徵とする。堆積盆は構造運動 を反映し，タービダイトはこれらの堆積盆を埋積し ていくように発達する。つまり，これら異なった堆 積様式でタービダイトが発達するのは，それぞれの 時代ごとに堆積盆と後背地を含む広域的な構造運動 が異なっていると言える。

今回調査した新潟・長野両県にまたがる富倉地域 (Fig. 1) は, 上部中新統から第四系の堆積岩が連続 して分布する。また，高野（1990）の田麦川層ター ビダイトの上流にあたり, 北部フォッサ・マグナ地 域の鮮新世の堆積盆解析のほか, 新潟と長野の層序 


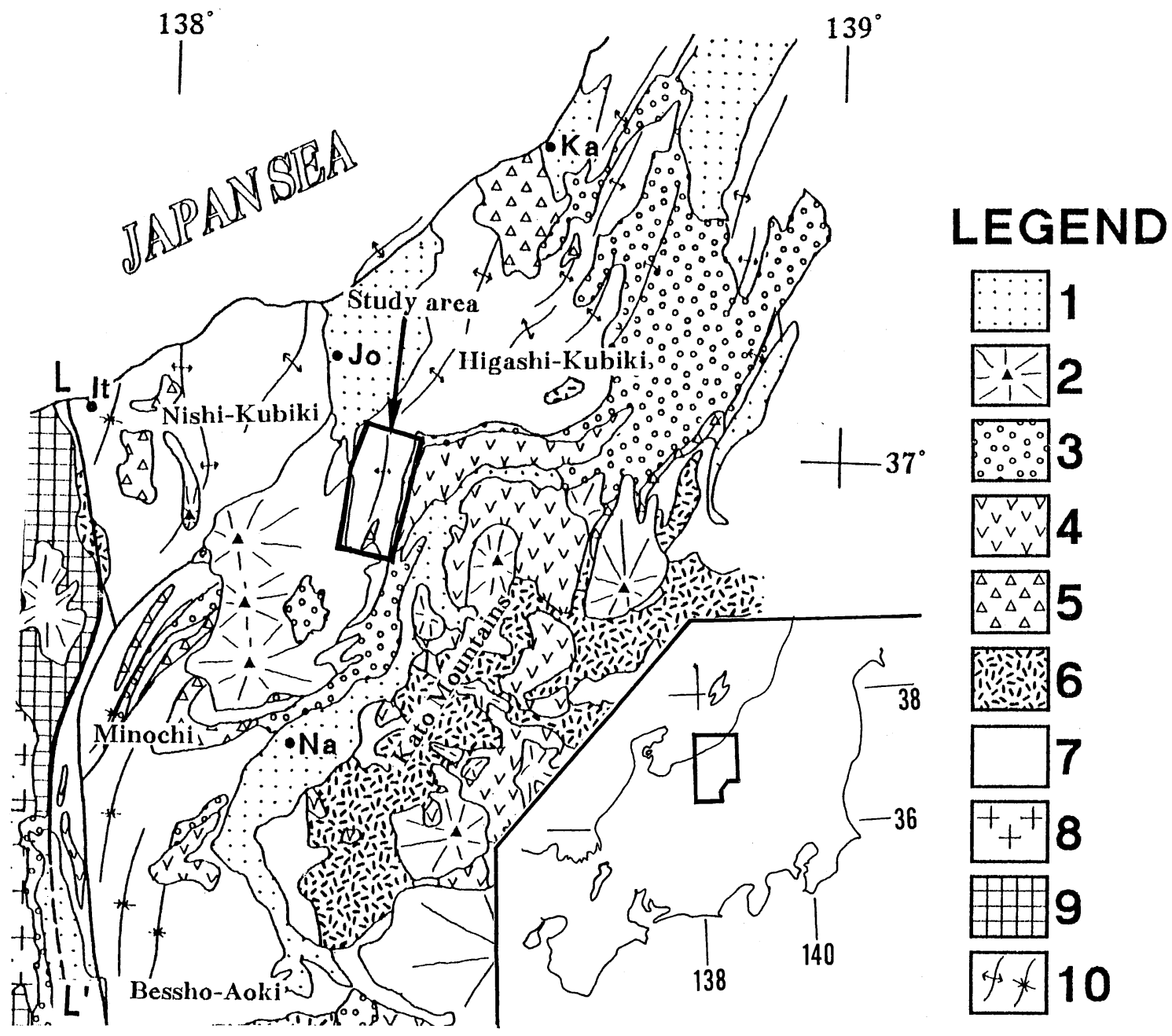

Fig.1 Locality map of northern part of the Fossa-Magna region. The study area is indicated by solid line. 1: Alluvium, 2: Quaternary volcanics, 3: Quaternary sediments, 4: Pliocene-Early Pleistocene volcanics, 5: Pliocene volcanics, 6: Middle Miocene volcanics, 7: Tertiary sediments, 8: Cretaceous-Paleogene granits, 9: Pre-Tertiary, 10: Fold axis. Jo: Joetsu, Ka: Kashiwazaki, Na: Nagano, It: Itoigawa, L-L': Itoigawa-Shizuoka Tectonic Line.

をつなげる上でも重要な地域である。今回の研究で は，本地域に分布する中新〜鮮新統上小沢層夕ービ ダイトについて堆積学的検討を行った。 その結果, 当時の堆積盆の形態と堆積物の発達様式が明らかに なったので、以下に結果を報告する。

\section{2. 地質概説}

本調査地域には，全層厚 $3000 \mathrm{~m}$ 以上の新第三系 上部中新統から第四系の堆積岩が広く分布し，下位 加富倉層，上小沢層，平丸層，土路層，猿橋層に 区分される（Fig. 2, 3).
富倉層（森島，1941）は, 主として黒色塊状泥岩 からなり，本層下部は調查地域南部では樽本火砕岩 部層（Saito, 1962）と指交する。本層中の下樽本凝 灰岩からは4.26Ma の F.T. 年代值が得られた。上小 沢層（新称）は，タービダイト堆積物からなり，富 倉背斜の両翼で岩相が異なる。背斜東翼では砂岩, 礫岩などの粗粒物が優勢であり，背斜西翼では砂岩 泥岩互層が優勢である（Fig. 4, 5). 本層は岩相の 違いにより下位より $\mathrm{A} \sim \mathrm{D}$ の 4 部層に細分できる。 本研究では，森島（1941）による富倉層の砂岩泥岩 互層部分と，中村（1982）による長沢層が一連の堆 


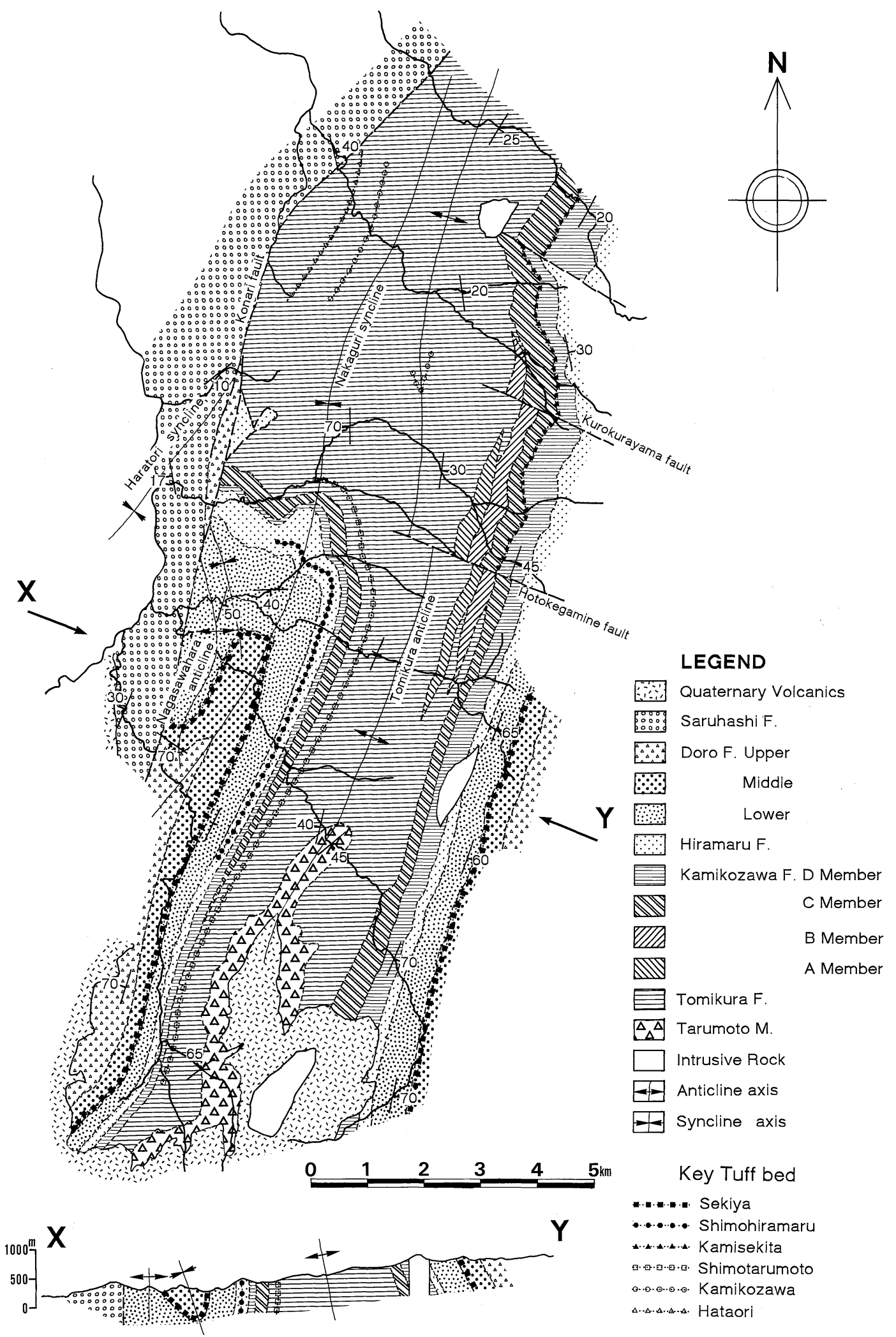

Fig.2 Geological map and cross-section of the Tomikura region. 


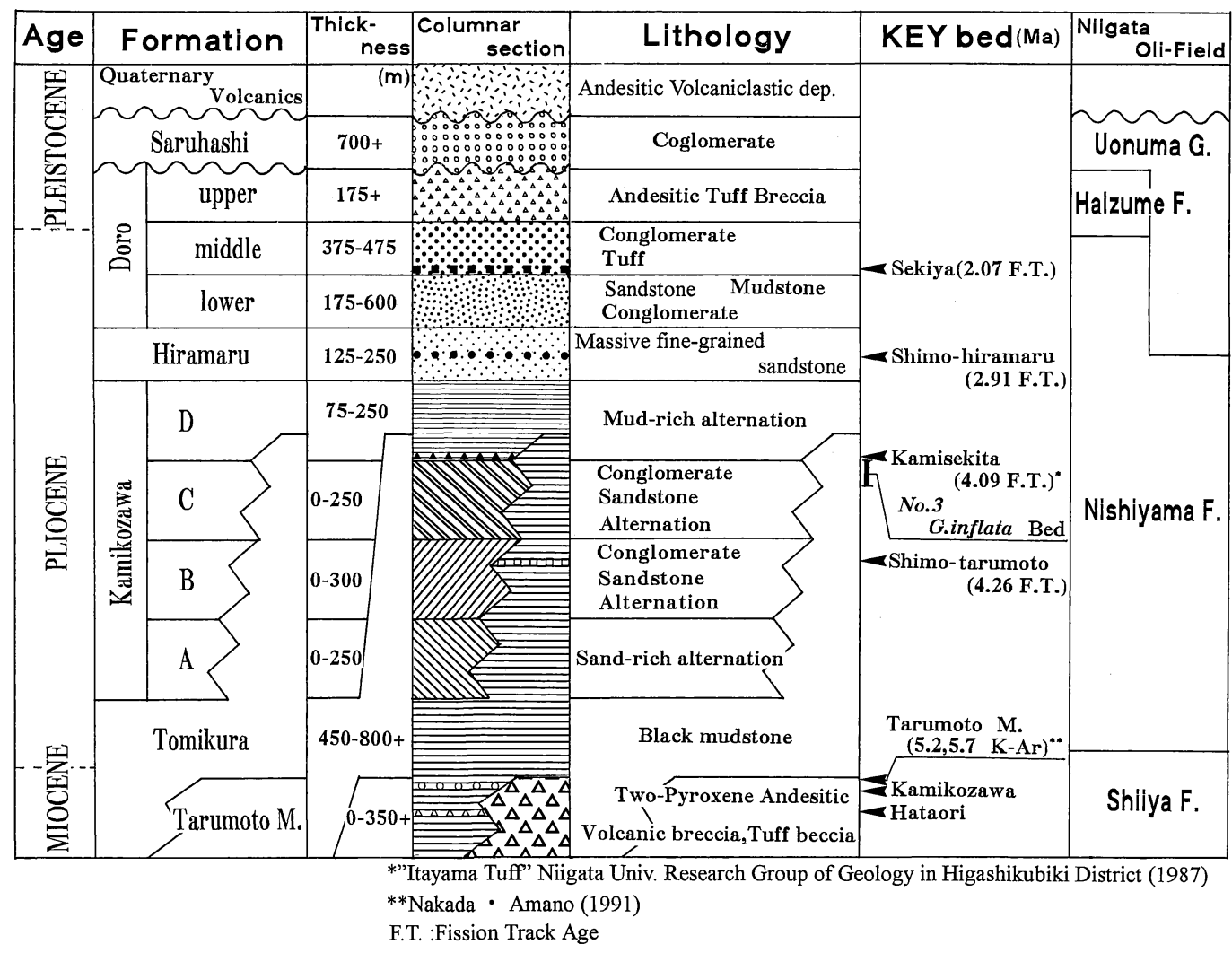

Fig.3 Generalized columnar sections and stratigraphic division in the Tomikura region.

積物であることが確認されたため，両層を一括し， 新たに上小沢層とした。また，本層に挟まれる上関 田凝灰岩（新称）は，重鉱物組成，火山ガラスの化 学組成，層厚の変化，古流向から判断して，本地域 の北東側に位置する東䅡城地域の板山凝死岩（新潟 大学東頚城地域地質調査グループ，1987）に対比さ れると推測される。ささらに，竹内（1990）によれば 上小沢層中に浮遊性有孔虫鍵層の No. 2 G.inflata bedの報告があるが, 今回の有孔虫化石分析の結果, これは No.2ではなく, No. 3 G.inflata bed である と認定された。平丸層（新称）は，主として青灰色 から灰色の塊状細粒砂岩からなる。本層中の下平丸 凝灰岩（黒川ほか（1995）による平丸パミス質火山 灰）から2.91Maの F.T. 年代值が得られた。土路層 （中村，1982）は, 主として砂岩, 礫岩, 泥岩から なり，岩相の違いにより，下，中，上部層に分けら れる。中部層基底の関屋凝灰岩（新称）からは, 2.07Ma の F.T. 年代值が得られた。猿橋層（森島, 1941）は，主として鿬岩からなる。なお，層序につ いての定義や詳しい記載については別稿にゆずる。

\section{3. 上小沢層の堆積学的検討}

\section{A）層相の区分と分布}

上小沢層に見られる層相を堆積相・堆積組相に細 分し，部層区分ごとにそれらの分布を記述する。

\section{1 ) 堆積相}

上小沢層は，以下のような堆積相からなる。 (Table 1)

碟岩相 $(\mathrm{Cg})$ : 層厚 $1 \sim 5 \mathrm{~m}$ の礫支持の中礫岩か らなり，礫径は数 $\mathrm{cm}$ から $20 \mathrm{~cm}$ に達する場合があ る．基質は粗粒砂～細礫からなる，多くの場合，級 化構造がみられ，時には，層の基底部に逆級化が見 られる事がある。級化構造を呈していないときは, 一般に塊状である。礫は小判状から球状まで認めら れ，しばしばインブリケート構造が発達する。また， 径数cm の泥岩の同時侵食礫（rip-up clast）を含む 場合がある。

含砂砂岩相 $(\mathrm{Ps})$ : 層厚 $1 \sim 3 \mathrm{~m}$ の塊状の極粗粒 から中粒砂からなり，中礫が無秩序に散在する。ま れに級化構造が認められることがあり，その場合， 


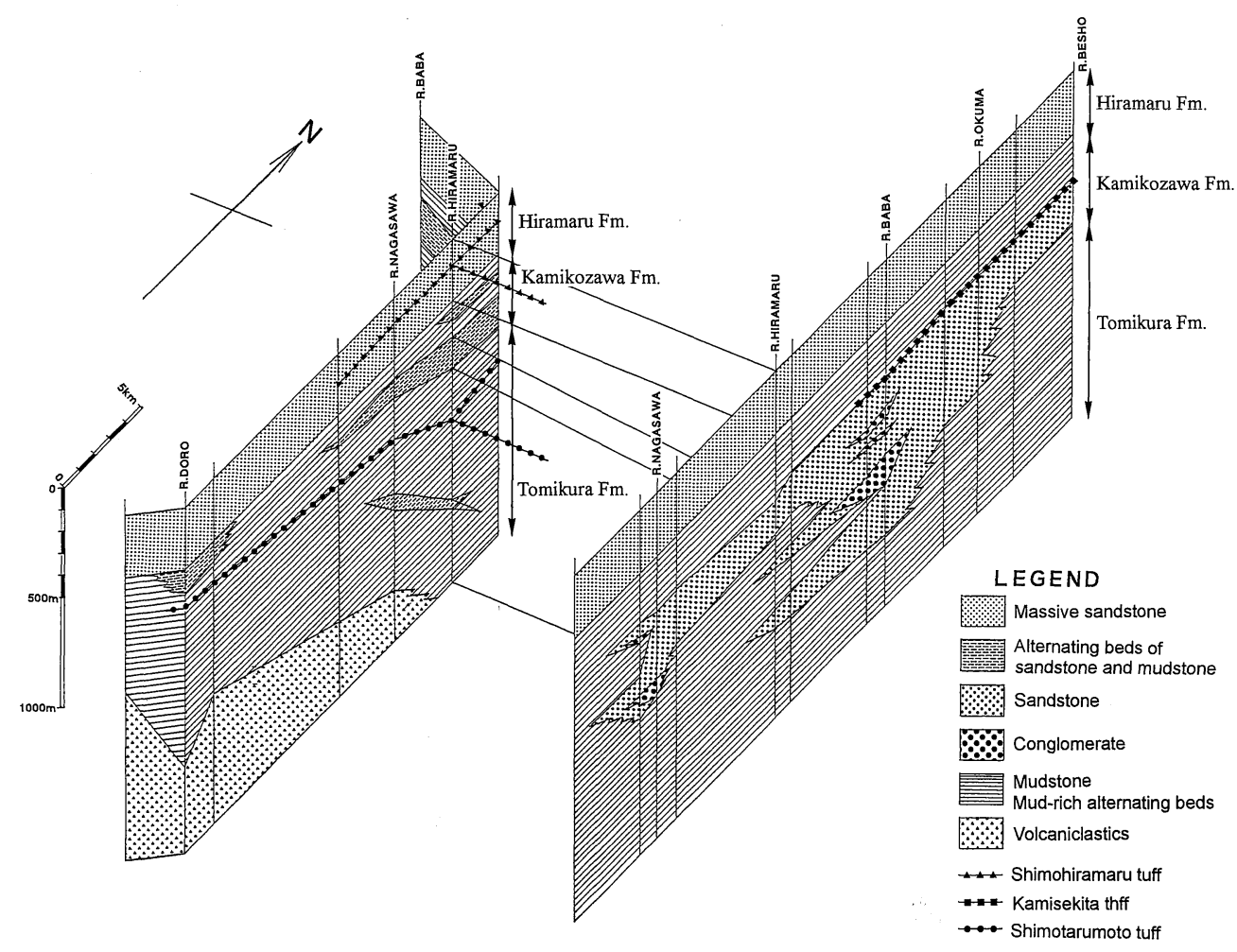

Fig.4 Panel diagram of the stratigraphic profile.

下位の礫岩相から漸移的に変化する。また, 礫岩相 と同様に, 径数 $\mathrm{cm}$ の泥岩の同時侵食礫（rip-up clast）を含む場合がある.

厚層砂岩相 (Ss) : 塊状の中粒砂からなる.層厚 は $1 \mathrm{~m}$ から $6 \mathrm{~m}$ に達するが，アマルガメーション が頻繁に認められ，それによって層厚が厚くなって いる，級化構造は基底部に見られ，粗粒砂～細礫か ら上方に級化する。一般には塊状であるが，全体に 弱い平行葉理が発達する場合がある。

砂岩優勢砂岩泥岩互層相（As）：層厚 $20 \mathrm{~cm}$ 加 $1 \mathrm{~m}$ の砂岩/泥岩ユニットが有律に重なる互層で ある．砂泥比は 5：1 以上である．砂岩は粗粒〜中 粒砂からなる。アマルガメーションはまれにしか認 められない. 砂岩部は一般に, Bouma sequence (Bouma, 1962) のE部に級化し，Tae を形成する.

等量砂岩泥岩互層相 $(\mathrm{An})$ : 砂泥比が 1 前後の有 律な互層である。エニットの層厚は 5 ～15cm であ る。砂岩部は中粒〜細粒砂からなる。全体に Bouma sequence が発達し, Tabe, Tabce, Tbce, Tbe が観察される.

泥岩優勢砂岩泥岩互層相 $(\mathrm{Am})$ : 砂泥比が $1 / 2$ 以
下の有律な互層である。砂岩部は細粒砂〜シルトか らなり, Bouma sequenceの Tde が観察される. ユニットの層厚は $5 \sim 10 \mathrm{~cm}$ である。

含碩泥岩相 $(\mathrm{Pm})$ : 非常に不淘汰な泥岩からなる 基質中に, 中磼〜細磎が散在する。一般には塊状で あるが，一部に基底部が礫層からなり，碟支持の磁 岩相から上方に向かって，基質支持の含礫泥岩相に 級化している場合がある. 層厚は, 3〜8 mである.

スランプ相 $(\mathrm{Sl})$ : 層厚は $3 \sim 5 \mathrm{~m}$ である. 径 10 ～20cm の砂岩のブロックを多量に含み，砂岩ブロ ックには Bouma sequence が見られるものもある. 基質は細礫〜粗粒砂からなる。

泥岩相 (Ms) : 暗灰色から青灰色の塊状泥岩から なる。まれに砂岩層を挟む場合がある。

これらの堆積相区分は, Walker \& Mutti（1973） によるタービダイトとその随伴堆積物の層相区分に ほほ対応している。また，砂岩泥岩互層には Bouma sequence が発達し, 礫岩の基底部では逆 級化相が見られ, 含礫泥岩相が発達することから, 上小沢層を構成する地層の大部分はタービダイトな ど堆積物重力流による堆積物であると言える。 


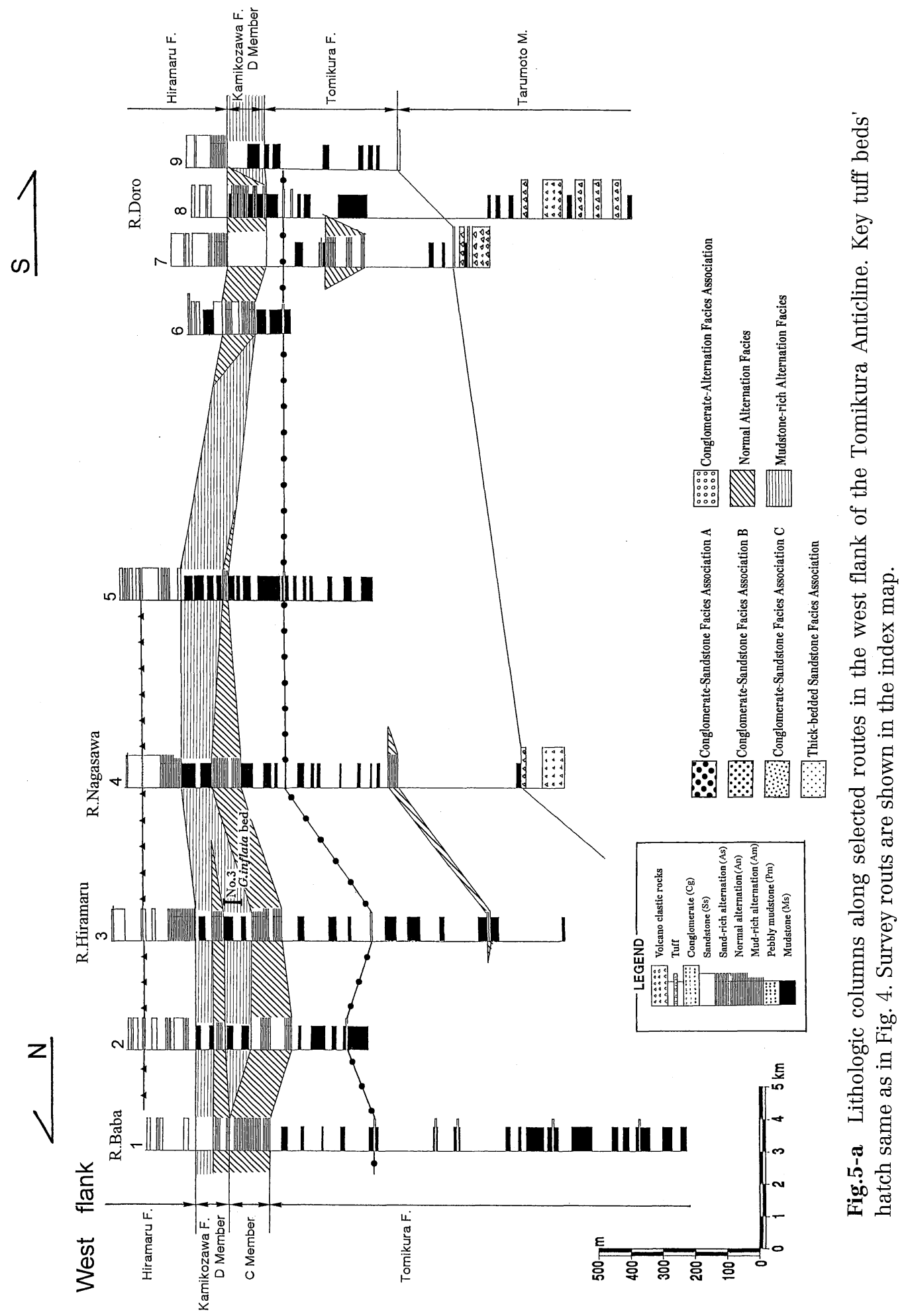




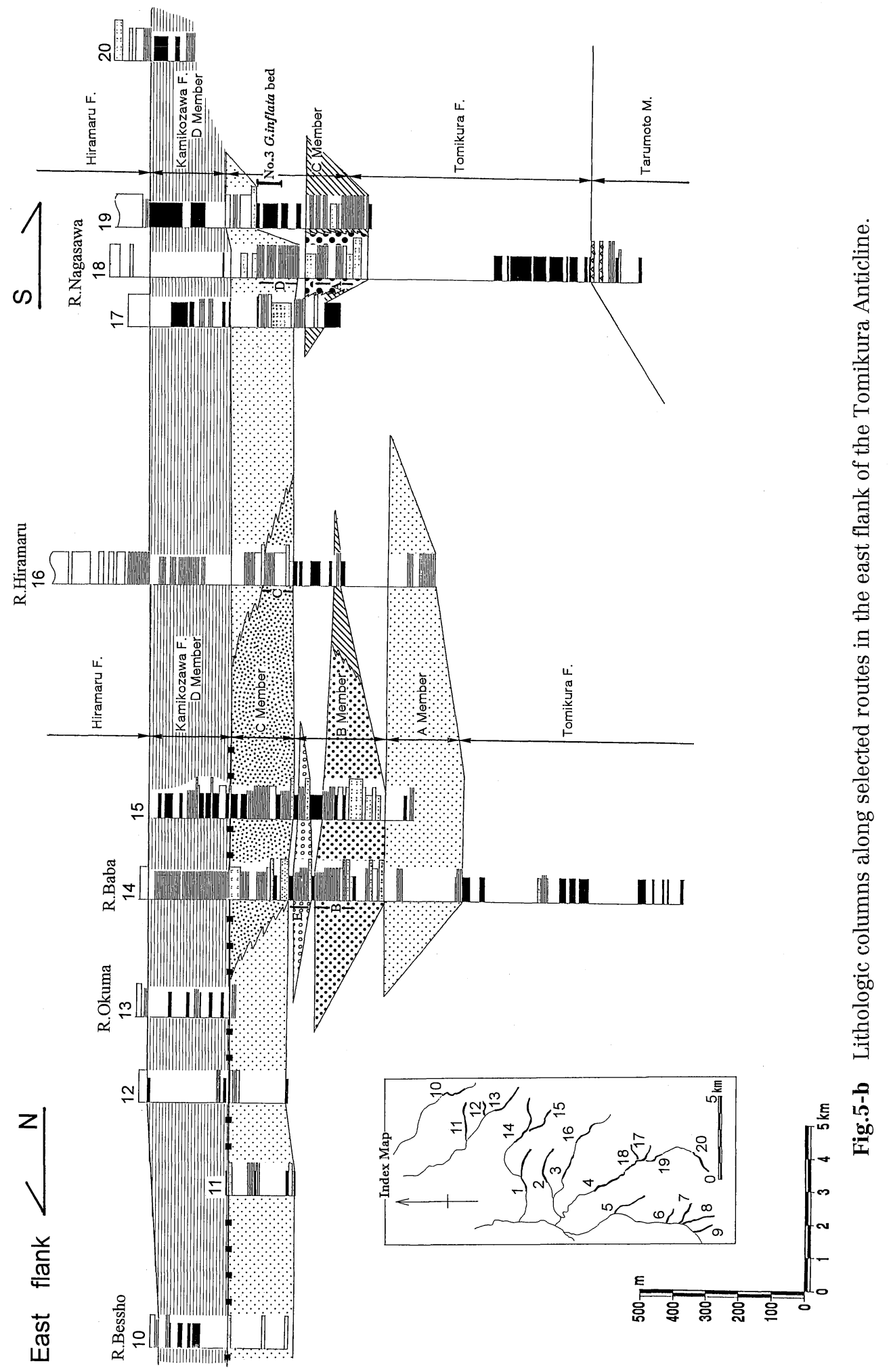


Table 1 Facies classification of the Kamikozawa Formation.

\begin{tabular}{|c|c|c|}
\hline \multicolumn{2}{|r|}{ FA C I E S } & Walker \& Mutti(1973) \\
\hline $\mathrm{Cg}$ & $\begin{array}{l}\text { Conglomerate } \\
\cdot \text {-thickness } 1 \sim 5 \mathrm{~m} . \\
\cdot \text {-clasts' diameter } 5 \sim 20 \mathrm{~cm} \text {. matrix: coarse } \sim \text { fine sand. } \\
\text { ·normal grading. base: inverse grading(rare). } \\
\text { - imbricate structure. } \\
\text {-rip-up clast. }\end{array}$ & $\mathrm{A} 1, \mathrm{~A} 2$ \\
\hline Ps & $\begin{array}{l}\text { Pebbly Sandstone } \\
\text {-thickness } 1 \sim 3 \mathrm{~m} \text {. grain size: medium } \sim \text { very coarse sand. } \\
\text { ·rarely normal grading. } \\
\text {-rip-up clast. }\end{array}$ & $\mathrm{A} 3, \mathrm{~A} 4$ \\
\hline Ss & $\begin{array}{l}\text { Thick Bedded Sandstone } \\
\cdot \text { thickness } 1 \sim 6 \mathrm{~m} \text {. grain size: medium } \\
\text {-massive. weakly laminated. } \\
\text {-amalgamation. } \\
\end{array}$ & \multirow[b]{2}{*}{$\mathrm{B} 2$} \\
\hline As & $\begin{array}{l}\text { Sand-rich Alternation } \\
\cdot \text { rhythmical. thickness } 20 \mathrm{~cm} \sim 1 \mathrm{~m} . \cdot \cdot \text { sand: } \mathrm{cs} \sim \mathrm{ms} \text {. } \\
\cdot \text { sand / mud ratio }>5: 1 . \\
\text {-rarely amalgamated or not. } \\
\cdot \text { Bouma sequence Tae. }\end{array}$ & \\
\hline An & $\begin{array}{l}\text { Normal Alternation } \\
\cdot \text { rhythmical. thickness } 5 \sim 15 \mathrm{~cm} . \cdot \text { sand: } \mathrm{ms} \sim \mathrm{fs} \text {. } \\
\cdot \text {-sand / mud ratio } 1 . \\
\text { ·Bouma sequence Tabe Tabce Tbce Tbe. }\end{array}$ & $\mathrm{C}$ \\
\hline Am & $\begin{array}{l}\text { Mud-rich Alternation } \\
\cdot \text { rhythmical. thickness } 5 \sim 10 \mathrm{~cm} \text {. ·sand: fs } \sim \text { silt. } \\
\cdot \text { sand } / \text { mud ratio }<1 / 2 . \quad \cdot \text { Bouma sequence Tde. }\end{array}$ & $\mathrm{D}$ \\
\hline Ms & $\begin{array}{l}\text { Mudstone } \\
\text {-dark gray blueish gray. } \\
\text {-rarely sand bed. }\end{array}$ & $\mathrm{G}$ \\
\hline $\mathrm{Pm}$ & $\begin{array}{l}\text { Pebbly Mudstone } \\
\text { ·thickness } 3 \sim 8 \mathrm{~m} \text {. contains pebble gravel. } \\
\text { ·massive. ·rarely normal grading. }\end{array}$ & \multirow{2}{*}{$\mathrm{F}$} \\
\hline Sl & $\begin{array}{l}\text { Slump breccia } \\
\cdot \text { thickness } 3 \sim 5 \mathrm{~m} \text {. matrix: granule } \sim \text { coarse sand. } \\
\cdot \phi 10 \sim 20 \mathrm{~cm} \text { sandstone block. }\end{array}$ & \\
\hline
\end{tabular}

\section{2 ) 堆積組相 (Facies Association)}

上述の堆積相のうち, 粗粒な堆積相は, 以下のよ うな系統的な随伴関係を有し, 堆積組相を形成する. 各組相の代表的な堆積柱状を Fig. 6 に示す.

\section{・踩岩砂岩組相}

一般に, 含礫泥岩相 (Pm) から始まり, 磁岩相 $(\mathrm{Cg})$, 含啋砂岩相 $(\mathrm{Ps})$, 厚層砂岩相 $(\mathrm{Ss})$, 等量 砂泥互層相 $(\mathrm{An})$ と変化し，泥岩優勢砂泥互層相 (Am) 八至る上方細粒化, 薄層化サクセションを構 成する。スランプ相（Sl）を伴う場合もある。サク セション下部の含礫泥岩相 $(\mathrm{Pm})$, 礫岩相 $(\mathrm{Cg})$ の出現状況により，さらに $\mathrm{A} \sim \mathrm{C}$ の 3 タイプに細分 される。

・鿬岩砂岩組相A（Fig. 6, A）

本組相は，最下部に塊状で泥岩の浸食礫をかなり含 む鿬岩相 $(\mathrm{Cg})$ ，その上位に礫支持から基質支持に 級化構造を示す含磼泥岩相 $(\mathrm{Pm})$, 礫岩相 $(\mathrm{Cg})$, 細㗂からの級化がよく見られる厚層砂岩相 $(\mathrm{Ss})$ と
続き，以下，等量砂泥互層相 $(\mathrm{An})$ ，泥岩優勢砂泥 互層相 $(\mathrm{Am})$ と変化する上方細粒化，薄層化サク セションを構成する。これらの上方細粒化, 薄層化 サクセションは，基底部から $5 \sim 15 \mathrm{~m}$ オーダーの 上方細粒化サクセションを繰り返しながら全体とし て約 $60 \mathrm{~m}$ オーダーのサクセションを構成する.

・礫岩砂岩組相 B (Fig. 6, B)

本組相は，磼岩砂岩組相 Aの基底部に見られる塊 状の礫岩相 $(\mathrm{Cg})$ が見られず，基質支持の含礫泥 岩相 (Pm) がサクセションの最下部を構成してい ることを特徴とする．全体としては礫岩砂岩組相 A と同様に 5 ～20m オーダーの上方細流化サクセシ ヨンを繰り返しながら含礫泥岩相 $(\mathrm{Pm})$, 磁岩相 $(\mathrm{Cg})$, 厚層砂岩相 $(\mathrm{Ss})$, 等量砂泥互層相 $(\mathrm{An})$, 泥岩優勢砂泥互層相 $(\mathrm{Am})$ と変化する約 $60 \mathrm{~m}$ オー ダーの上方細粒化，薄層化サクセションを構成する。

·礫岩砂岩組相 C (Fig. 6, C)

本組相には礫岩砂岩組相 A，B下部に見られる含 


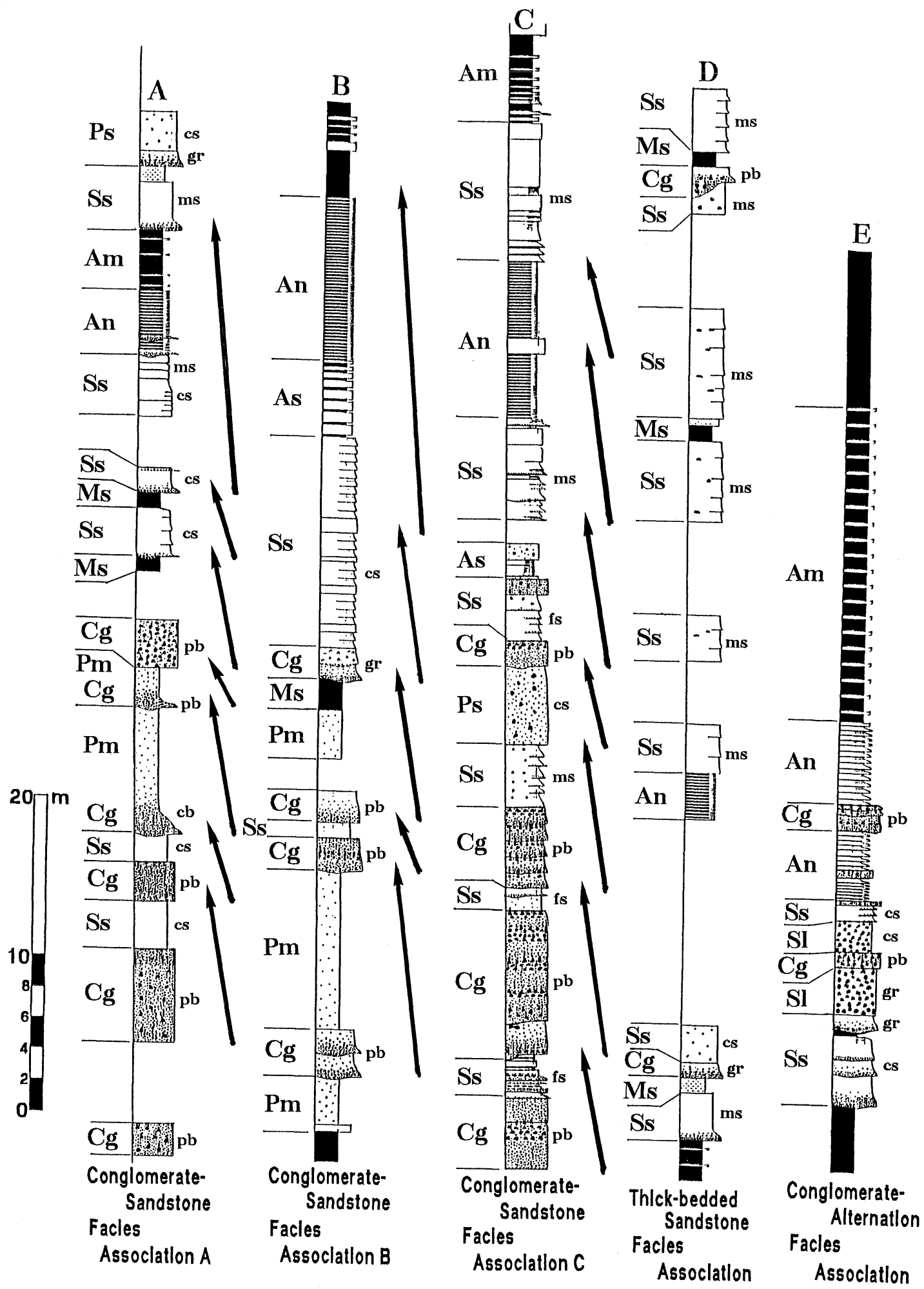

Fig.6 Typical sedimentological columns of facies associations, shown in Fig. 5. Abbreviations indicated at the left hand of the columns mean facies division. Abbreviations indicated at the right hand of the columns mean grain size. 
礫泥岩相（Pm）が存在しないことが特徵である. 全体としては礫岩相（Cg）から始まり，5～10m オーダーの上方細粒化サクセションを繰り返しなが ら含磁砂岩相 $(\mathrm{Ps})$, 厚層砂岩相 (Ss), 等量砂泥互 層相 $(\mathrm{An})$ と変化し, 泥岩優勢砂泥互層相 (Am) へ至る上方細粒化, ‘薄層化サクセションを構成する。

- 厚層砂岩組相 (Fig. 6, D)

主として，厚層砂岩相（Ss）功なる $40 ７ 0 \mathrm{~m}$ オーダーのユニットから構成されるが，一部には含 礫砂岩相 (Ps), 礫岩相 (Cg) を伴い不明瞭ながら 上方細粒化，薄層化サクセションが認められる場合 がある。

-礫岩砂泥互層組相 (Fig. 6, E)

主に，等量砂岩泥岩互層相（An）からなり，組 相の下部に厚層砂岩相 $(\mathrm{Ss})$, 礫岩相 $(\mathrm{Cg})$ を伴う. まれに，スランプ相（Sl）を伴う場合がある．厚層 砂岩相 $(\mathrm{Ss})$, 礫岩相 (Cg) には泥岩の浸食磼が含 まれる。

\section{3 ）堆積相・堆積組相の出現状態と層序}

上小沢層の各部層と, 出現する堆積相・堆積組相 との関係は，以下の様になっている（Fig. 5).

\section{・ A 部層}

調査地域中央部を南北に伸びる富倉背斜東翼 (Fig. 5b) では，平丸川（ルート16）と馬場川流域 （ルート14，15）に厚層砂岩組相が分布するほかは, 富倉層の泥岩相（Ms）が分布する。ただし，大熊 川流域（ルート11〜13），別所川（ルート10）では 露出が極めて悪いので明かではないが，僅かに露出 している岩石や，周りの地形から判断して，同様な 泥岩相 $(\mathrm{Ms})$ が分布していると推測できる。背斜 西翼（Fig. 5a）では，A部層は存在せず，富倉層と して泥岩相（Ms）が分布している。背斜東翼のA 部層の層厚は馬場川で最も厚く，南北方向には層厚 が減少し，富倉層の泥岩相（Ms）に移化する。

$\cdot \mathrm{B}$ 部層

富倉背斜東翼（Fig. 5b）では，馬場川流域（ル 一ト14，15）に礫岩砂岩組相Bが分布する。馬場川 より南方の平丸川（ルート16）では泥岩優勢砂岩泥 岩互層相（Am）が分布し，更に南方の長沢川（ル ート17）では富倉層の泥岩相（Ms）が分布する. 馬場川北方の大熊川流域（ルート11～13），別所川 （ルート10）では露出が良くないが，A部層と同様 に泥岩相（Ms）が分布していると推測できる。背 斜西翼（Fig. 5a）では，A部層と同様に B 部層も存 在せず全般的に泥岩相（Ms）が分布しているが，
平丸川（ルート 3 ），長沢川（ルート4）では，か なり薄い層であるが等量互層相 (An) が分布する. 背斜東翼の $\mathrm{B}$ 部層の層厚は馬場川で最も厚く，南北 方向には層厚が減少し，富倉層の泥岩相（Ms）に 移化する。また，礫岩の礫径は馬場川で最も大きく， 北方に径を減少させる. 南方は露出が無いため, 不 明である。

・ C 部層

富倉背斜東翼（Fig. 5b）では，全般的に厚層砂 岩組相が分布するが，馬場川流域（ルート14，15） では礫岩砂岩組相Cが分布する。また，長沢川（ル 一ト18）では磼岩砂岩組相Aが分布し，すぐ隣の沢 （ルート17，19）では等量砂岩泥岩互層相 (An) が 分布する。背斜西翼 (Fig. 5a) では等量互層相 （An）が分布するが，南方の土路川流域（ルート 6 ～9）では富倉層の泥岩相（Ms）が分布する。層 厚は, 東翼は水平方向に変化は見られないが，西翼 では馬場川で最も厚く，南方へ層厚を減少させ，富 倉層の泥岩相 (Ms) に移化する. 北方へは木成断 層によって分布が限られているので不明である。礫 岩の磁径は長沢川で最も大きく, 北方へ減少させる。 馬場川で再び礫径が大きくなり北方へ減少する。

- D 部層

富倉背斜両翼で，泥岩優勢砂岩泥岩互層相 $(\mathrm{Am})$ が分布する。背斜西翼（Fig. 5a）の土路川流域（ル ート 6 ～9）では等量砂岩泥岩互層相 (An) が分 布する。また, 背斜東翼の馬場川流域（ルート14, 15）で，まれに厚層砂岩相（Ss），砂岩優勢砂岩泥 岩互層相（As）を挟む。層厚は東翼が厚く，西翼 は東翼に比べ薄い.

\section{B ) 古流系 (Fig. 7)}

礫岩に発達するインブリケーション，砂岩層に発 達する Bouma sequence（Bouma, 1962）の Tc 斜 交葉理部に見られるフォアセットラミナ，砂岩碟岩 層の基底部に発達するソールマーク，および，砂岩 層の grain fabric を用いて, 上小沢層の古流系を解 析した。

上小沢層全体を通して，南南西から北北東方向へ 向かう古流向を示すが，一部は南北方向から南南 東一北北西方向を示す。また，富倉付近では，磁の インブリケート構造から西方向へ向かう古流向が得 られた。 


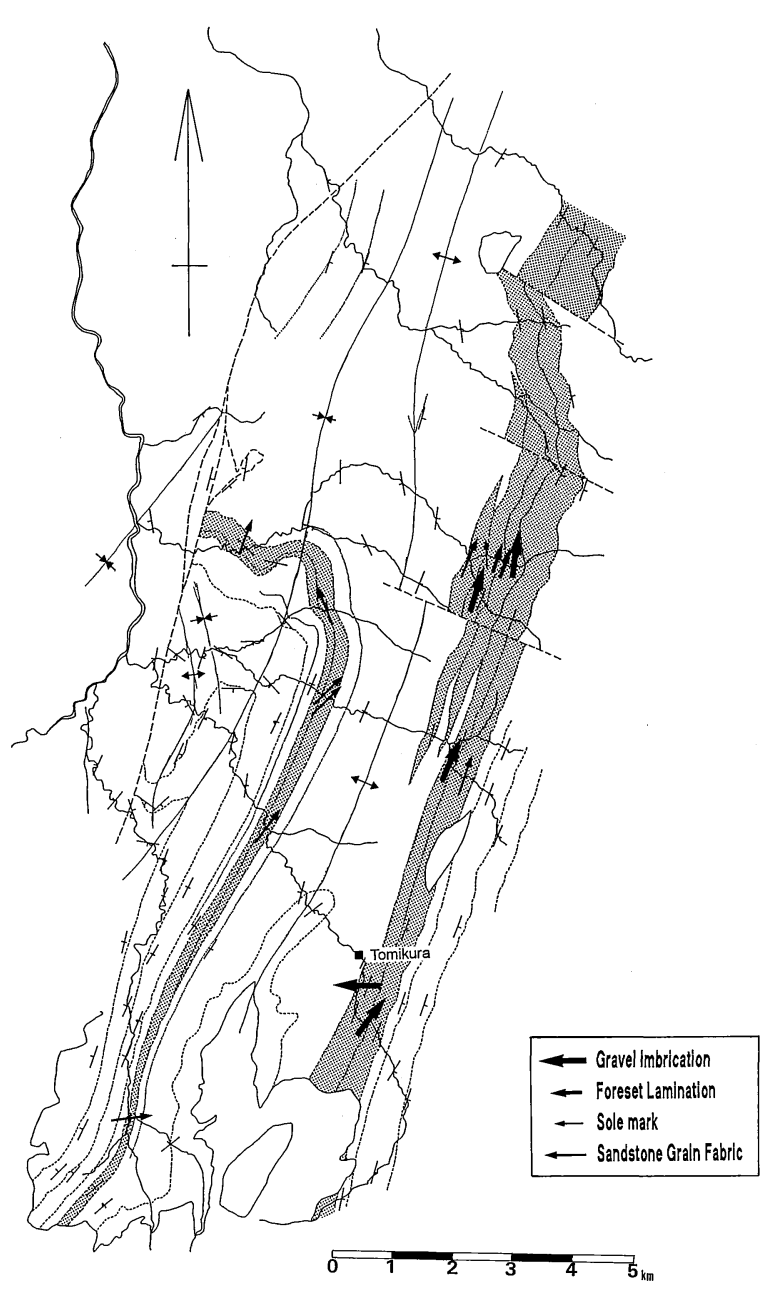

Fig.7 Paleocurrent directions of the Kamikozawa Fomation. The Kamikozawa Formation is indicated by dotted areas.

\section{C）礫種組成（Fig. 8)}

上小沢層に含まれる磁岩の礫種組成を明らかにす るため, Fig. 8 に示す合計 8 地点において, 礫岩の 露頭の $50 \mathrm{~cm} \times 50 \mathrm{~cm}$ のグリッドから，粒径に関係な く約50〜100個の礫を採集し、これらについて礫種 と粒径を調べた。礫種については, 個数\%で示した。

上小沢層中の礫岩の磁種は, 安山岩, 流紋岩, 濃 飛流紋岩などの火山岩類と, 砂岩, 頁岩, チャート などの古期堆積岩類からなり, 上小沢層全体を通し て礫種は変わらない。しかし，組成比は場所により 変化する．礫岩が厚く発達するところでは安山岩の 含有量が多く, 古期堆積岩類は少ない（Fig. 8の 5, 8 地点). その地点から離れると, 安山岩の含有量
が少なくなり，代わりに古期堆積岩類の含有量が多 くなる (Fig. 8 の 1, 2, 7 地点)。また, 粒径から みても, 碟岩の厚く発達する所では安山岩の砂径も 大きく (Fig. 8 の 5,8地点)，離れるにつれ礫径が 小さくなる傾向にある (Fig. 8 の $1,2,7$ 地点). 安山岩以外の礫についても同様の変化を示すが，安 山岩より礫径は小さい.

\section{4. 考 察}

\section{A）上小沢層の堆積環境 \\ 1) 堆積盆の形態}

先に述べたように，上小沢層を構成するタービダ イトは富倉背斜の両翼に分かれて分布している。夕 ービダイトは背斜両翼で異なる堆積相・堆積組相を 示し，背斜西翼では北西方向に層厚を増す傾向にあ ることなどから（Fig. 4, 5)，上小沢層のタービダ イト堆積盆は, 富倉背斜の両翼に存在した異なる堆 積盆を埋積していたと考えられる。個々の堆積盆の 形態は，調査できる上小沢層の範囲が東西方向にお いて限られているので明確ではないが，堆積相・堆 積組相が南西から北東方向に，より細粒な岩相を示 すように分布していること（Fig. 5)，古流向も同様 に南西から北東方向へ向かう流れが卓越すること (Fig. 7) から判断すると, Mutti \& Ricci-Lucchi （1972）による海底扇状地モデルではなく，Underwood \& Bachman (1982) や高野 (1990) のトラ フ状の堆積盆であると推測できる。よって上小沢層 のタービダイト堆積盆は, 富倉背斜の両翼で北北東 方向に 2 本並走して延びるトラフ状タービダイト堆 積盆であると推定される。この伸長方向は新潟新第 三系堆積盆の伸長方向に平行であり，北東への延長 方向には高野（1990）の田麦川古海底トラフが存在 する。富倉地域のトラフの規模は，分布が限られる ため不明であるが，延長 $10 \mathrm{~km}$ 以上，幅は少なくと も背斜西翼のトラフで $6 \mathrm{~km}$ 以上，東翼のトラフで $2 \mathrm{~km}$ 以上と推定できる。背斜東翼のトラフは，幅 や埋積する堆積物から判断すると，トラフよりむし ろチャネル状トラフと言った方がよい.

\section{2 ) 砕屑物の供給源}

上小沢層の古流向の解析では，全体的に北北東方 向のトラフ軸流として砕屑物が供給されたことを示 している。しかし，上小沢層は東翼と西翼で大きく 岩相が異なる。西翼の砕屑物はトラフ軸流によって 運ばれたものと考えられるが，東翼の粗粒砕屑物は 軸流の上流方向へは泥岩に移化し尖滅してしまうこ 


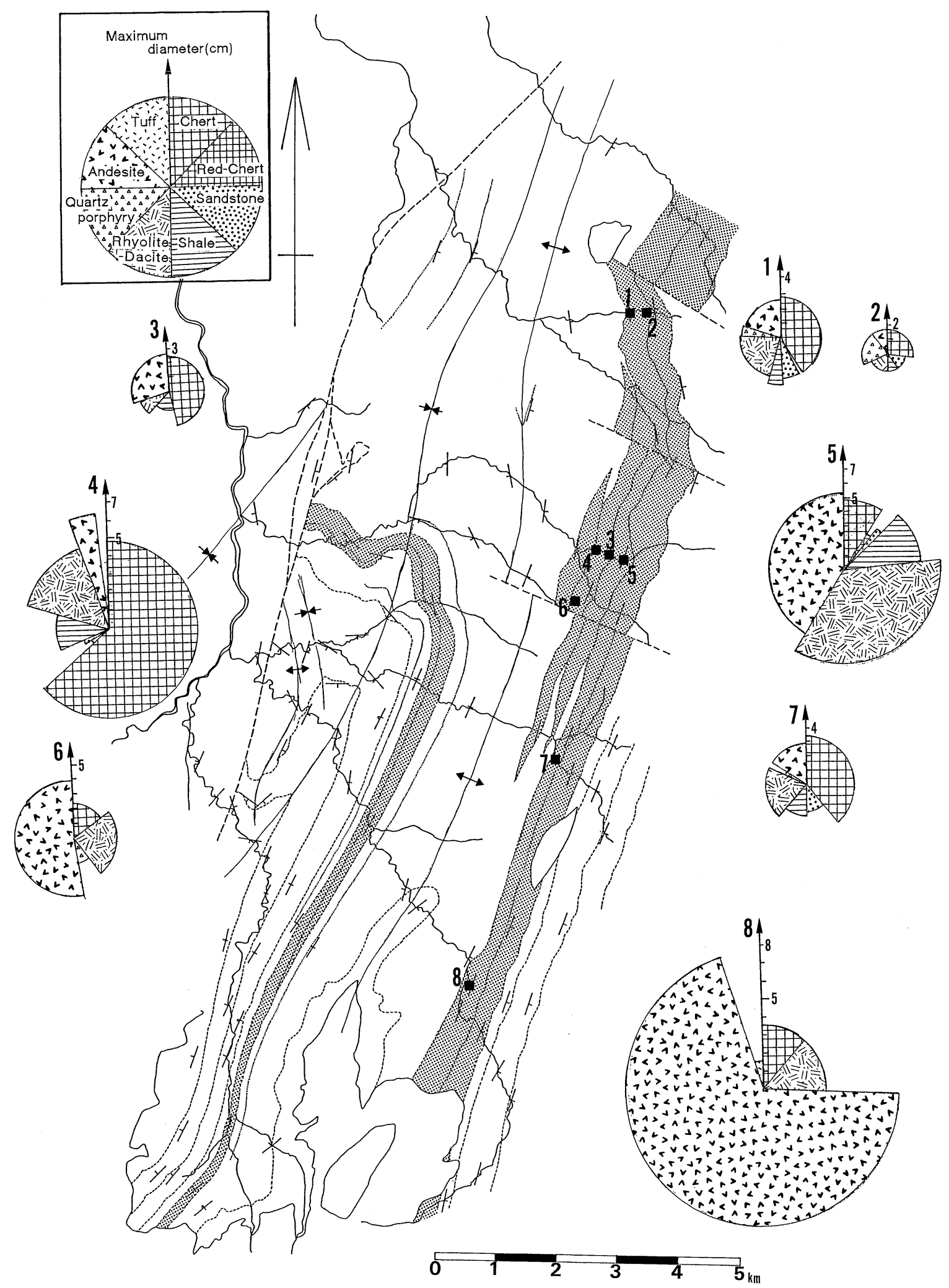

Fig.8 Maximum size and composition of gravels of conglomerate in the Kamikozawa Formation. 
とから, 同じトラフ軸流による供給とは考え難い. もし同じ供給源であるとするならば，両翼のトラフ にも同様な堆積物が発達するはずである。つまり， 西翼と東翼では供給源が異なることが考えられる。 上小沢層の礫種組成分析結果（Fig. 8）功すると, 東翼の粗粒砕屑物の後背地には火山岩類と基盤岩類 が分布していることが示唆される.富倉地域の南南 東方向の長野県河東山地には毛無火山, 志賀火山群 （五十嵐ほか，1984）の基盤である上部中新統の安 山岩類（八木，1941）が分布すること（Fig. 1）か ら，上小沢層の安山岩を含む粗粒砕屏物は南南東方 向の河東山地から供給されたと考えられる。

\section{3 ）堆積相と堆積環境}

堆積相・堆積組相の分布の状態（Fig. 5）および 古流向（Fig. 7）と, Tanaka（1989）の和泉層群に おける堆積モデルとを比較すると, 次のような堆積 環境が推定される。

主に富倉背斜東翼の上小沢層を構成する組相であ る礫岩砂岩組相は，泥岩同時侵食磁を含み，侵食構 造がみられること，典型的な上方細粒・薄層化サク セッションが認められること，またそれらの分布や 古流向などから，チャネル状トラフを埋積する堆積 物と考えられる。これらは，Mutti (1977) の paleo-submarine channel-fill deposit や, 保柳 · 大上（1986）の北海道中新統古丹別層のチャネル充 填堆積物に層相が類似する。

その中で，富倉付近の長沢川（Fig. 5b, 16）沿い の上小沢層 $\mathrm{C}$ 部層に発達する礫岩砂岩組相 $\mathrm{A}$ は, 基 底の含礫泥岩相の下部に礫支持の部分が発達するこ となどから, Tanaka (1989) の Upper-channel association に層相が類似する。さらに隣の沢 (Fig. 5b, 17, 19) では levee 相と考えられる等量砂 岩泥岩互層相が存在することから, main channel 相と推定される。

礫岩砂岩組相 B は馬場川沿い（Fig. 5b, 14-15） の上小沢層 B 部層に発達する。礫岩砂岩組相 $\mathrm{A}$ との 直接的な関係は不明であるが，基底の含礫泥岩相の 下部に礫支持部が発達しないことや，礫岩砂岩組相 Aよりも細粒な砕屑物によって構成されていること など, Tanaka (1989) の Lower-channel association に層相が類似することから，チャネル充填堆積 物であるものの礫岩砂岩組相 Aよりも distal な部分 で堆積したものと推定できる.

礫岩砂岩組相 C は平丸川 (Fig. 5b, 16), 馬場川 沿い（Fig. 5b, 14-15）の上小沢層 C 部層に発達す
る，基底の含礫泥岩相を欠き，礫岩砂岩組相 Bより も細粒な砕屑物によって構成されていることから， 礫岩砂岩組相 Bよりさらに distal な部分であると考 えられる。また周囲には厚層砂岩組相が分布し, levee 相が存在しないことから，磁岩を伴う distributary channel 相と推定される.

厚層砂岩組相は礫岩砂岩組相と同じく背斜東翼の 上小沢層を構成する組相で，上小沢層 $\mathrm{A}$ 部層および 長沢川（Fig. 5b, 17-19），大熊川沿い（Fig. 5b, 11-13), 別所川（Fig. 5b, 10）のC部層に発達する. この組相は磁岩砂岩組相Cの周辺に分布することか ら，相対的に礫岩砂岩組相 $\mathrm{A}$ およびBの下流側に存 在することがわかる。また不明瞭ながら上方薄層化 サクセションが認められることから，Tanaka (1989) の distributary channel 相や, Underwood \& Bachman (1982) の thick sequence of channelized sandstone 相に相当すると考えられる，厚層 砂岩組相は, 礫岩砂岩組相 C と同じシステムである が, 礫岩砂岩組相Cよりも礫岩相の占める割合が少 なく, システム内の distal な部分であると考えられる.

礫岩砂泥互層組相は, 礫岩砂岩組相と互層を成し て分布する，スランプ相を挟在すること，礫と砂泥 互層の組み合わせであること，互層の砂岩部にチャ ネル構造が認められることなどから, チャネルから あふれて堆積した Underwood \& Bachman（1982） の levee \& overbank deposit 相であると考えられる.

富倉背斜西翼の上小沢層を構成する等量砂岩泥岩 互層相は，顕著な上方薄層化・厚層化サクションが 発達しないことから，舌状体を形成しない sheet flow によって堆積したと考えられる。これらは Tanaka (1989) の sheet flow turbidite association に対応すると考えられる。また，背斜東翼の上 小沢層礫岩砂岩組相の周辺に発達する等量砂岩泥岩 互層相は，チャネルからあふれ出したもので, levee \& overbank deposit 相に対応すると考えられ る.

上小沢層 $\mathrm{D}$ 部層を構成する泥岩優勢砂岩泥岩互層 相は，等量砂岩泥岩互層相の下流側に発達し，同じ 性質を持つ事から， sheet flow によるもので, Tanaka（1989）の distal sheet flow association に 対応すると考えられる。

泥岩相は，タービダイトの性質を持たず，スロー プの堆積物と考えられる。

\section{4 ) 堆積過程}

上小沢層は前述したように，背斜西翼のトラフと 
東翼のチャネル状トラフを埋積していくように発達 している. 各部層ごとでは，それぞれのトラフ内で, 以下のような堆積様式を示す（Fig. 9).

\section{- A 部層堆積時}

上小沢層 $\mathrm{A}$ 部層は, 富倉背斜東翼のみに存在し, 厚層砂岩組相から形成される。背斜東翼のチャネル 状トラフでは南方から砕屑物が供給され， distributary channel 相が形成された。西翼のトラフでは砕 屑物は供給されず, 富倉層の泥岩が堆積していった。

\section{- $\mathrm{B}$ 部層堆積時}

上小沢層 $\mathrm{B}$ 部層は， $\mathrm{A}$ 部層と同様に富倉背斜東翼 に存在し、主に礫岩砂岩組相Bから形成される。背 斜東翼のチャネル状トラフでは $\mathrm{A}$ 部層と同じトラフ 内に砕屑物が供給され, lower channel 相を形成し, 周辺に levee 相を形成した。また上小沢付近では, 一部が東翼のチャネル状トラフから西翼のトラフに あふれ出し levee \& overbank deposits 相が形成さ れた，西翼のトラフでは $\mathrm{A}$ 部層と同じく富倉層の泥 岩が堆積していったが, 一時期南方から火山砕屑物 が供給され， distal sheet flow 相として下樽本凝灰 岩を形成した。

\section{- $\mathrm{C}$ 部層堆積時}

上小沢層 $\mathrm{C}$ 部層は，富倉背斜東翼では主に磁岩砂 岩組相 C と厚層砂岩組相から形成され，背斜西翼で は主に等量砂岩泥岩互層相 $(\mathrm{An})$ から成る。背斜 東翼のチャネル状トラフでは南方から砕屑物が供給 され， distributary channel 相が形成された。 上小 沢付近では側方から粗粒砕屑物が供給され，チャネ ル状トラフ内に lower channel 相を, その下流側 に distributary channel 相を形成した。側方からの 供給によって，チャネル状トラフ内では一時的な 「せき止め状態」になり，上流からの砕屏物は平丸 付近の西翼のトラフ内にあふれ出し, levee \& overbank deposits 相を形成した. 背斜西翼のトラフで は南方から砕㾍物が供給され, sheet flow turbidite 相が形成された。

· D 部層堆積時

上小沢層 $\mathrm{D}$ 部層は，背斜東翼と西翼で同様な泥岩 優勢砂岩泥岩互層相からなる。D部層堆積時になる と背斜東翼のチャネル状トラフと西翼のトラフが一 緒になり，その結合したトラフ内に南方から砕屑物 が供給され，上樽本付近に sheet flow turbidite 相 を，その下流側に distal sheet flow 相を形成した. また，上小沢付近では側方から火山砕首物が供給さ れ, 上関田凝灰岩を形成した。

\section{B）上小沢層タービダイトの堆積様式の特徵}

富倉地域における上小沢層のタービダイトの堆積 様式の特徴として，まず富倉背斜の両翼で全く異な る岩相を呈する点をあげることができる。背斜西翼 のトラフでは sheet flow turbidite 相からなる，い わゆる「classical」なタービダイトによってトラフ が埋積されている。一方, 東翼のチャネル状トラフ では西翼より粗粒なチャネル充填堆積物によりチャ ネルが埋積されている。

東翼側のチャネル状トラフを埋積する堆積物の特 徵は以下のようである。幅が狭いトラフ内に粗粒砕 屑物が供給された場合, proximal から distal 方向 へ upper channel 相 (砂岩礫岩組相 A), lower channel 相 (砂岩磁岩組相 B), disributary channel 相 (砂岩磥岩組相 C), 厚層砂岩組相の順に分 布する。また，チャネルの側方に levee \& overbank deposits 相 (等量砂岩泥岩互層相または碟岩 砂泥互層組相）が分布することがある。これらの埋 積堆積物の中の岩相の変化は，供給源から近いか遠 いか，あるいは供給量が多いか少ないかに対応する。

また，西翼側のトラフを埋積する堆積物の特徵は 以下のようである。 proximal から distal 方向へ sheet flow turbidite 相 (等量砂岩泥岩互層相), distal sheet flow turbidite 相（泥岩優勢砂岩泥岩互 層相）の順に分布する。これらの岩相の変化も，供 給源から近いか遠いか，あるいは供給量が多いか少 ないかに対応している。

これらのトラフやチャネルを埋積する堆積様式 は, Underwood \& Bachman（1982）の狭長なトラ フやトレンチ内の堆積モデルや，Tanaka（1989） の上部白亜系和泉層群を形成した狭長な堆積盆内の 堆積モデルにほぼ当てはまる。

富倉地域は，北部フォッサ・マグナ新第三系堆積 盆における，1次集積地である水内地域から 2 次集 積地である東頚城地域へ砕屑物を供給するバイパス 地域であると考えられている（高野，1992）。しか しながら，バイパス地域であることは間違いないに しろ, 東翼に分布する粗粒砕屑物は, 礫種や砕屑物 の分布からすると, 水内地域からよりはむしろ河東 山地からの供給が主体であると考えられる。一方, 水内地域からの砕屑物の供給については, 古流向か らすると富倉背斜西翼に分布するトラフを通じて行 われた可能性がある。よって, 富倉地域は水内地域 から東澒城地域に連続するトラフと, 河東山地から 流入するチャネル状トラフの会合地域であると考え 

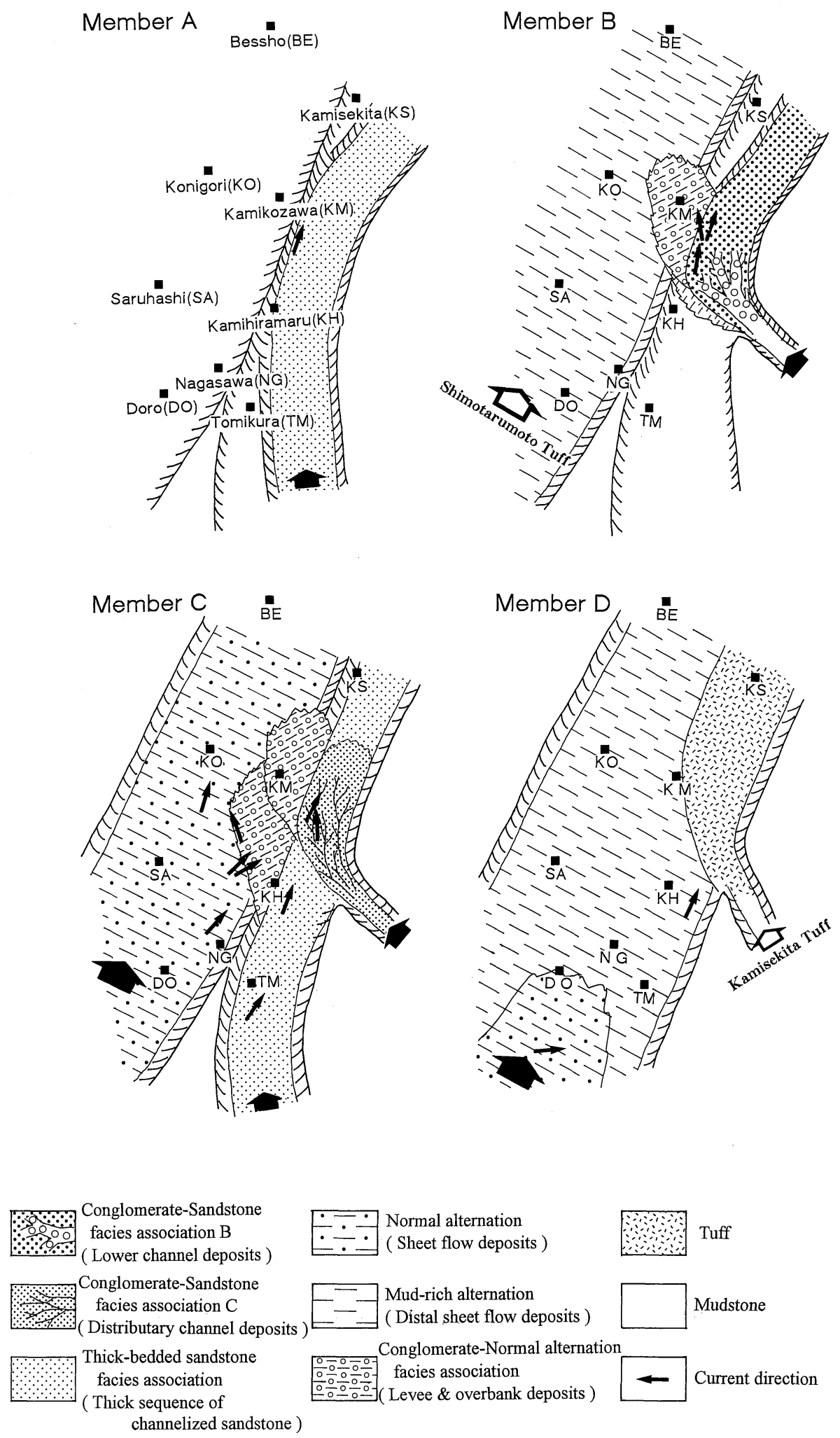

Fig.9 Schematic lithofacies maps at the depositional time of the Kamikozawa Formation. 


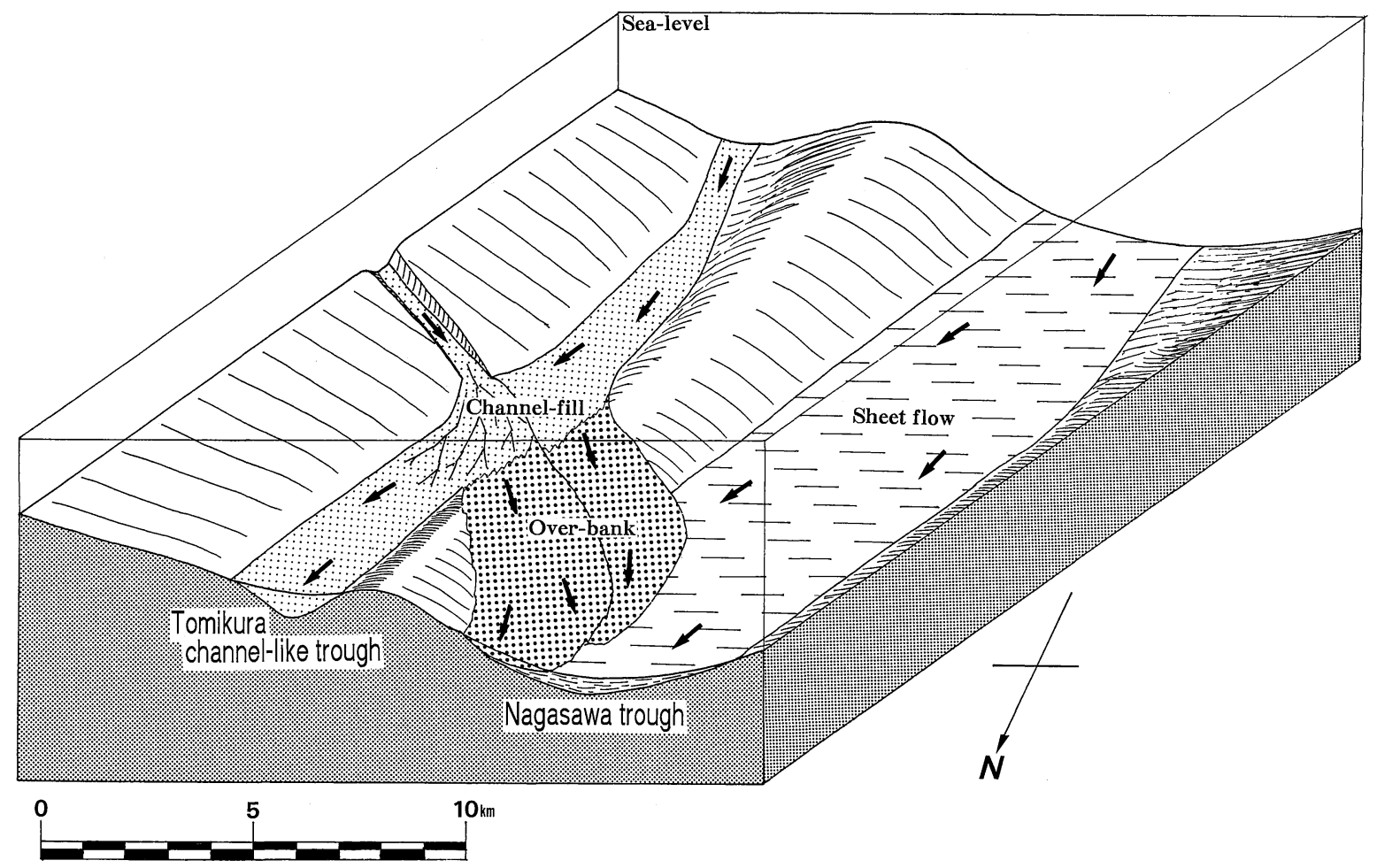

Fig.10 Depositional model of the Kamikozawa Formation.

\section{られる (Fig. 10).}

本論文では富倉地域に発達するタービダイトの形 態，発達様式の特徵について論じた。今後は，周辺 の地域，とくに上流の長野県側との関連を明らかに することによって，この当時北部フォッサ・マグナ 地域の地史や, 構造運動や海水準変動とのかかわり 合い, タービダイトの発生機構を解明できると思わ れる。

\section{5. まとめ}

上小沢層を構成するタービダイトについて堆積学 的検討を行った結果, 以下のことが明らかになった。 1.上小沢層タービダイトの堆積相は礫岩相, 含礫 砂岩相，厚層砂岩相，砂岩優勢砂岩泥岩互層相，等 量砂岩泥岩互層相, 泥岩優勢砂岩泥岩互層相, 含䃏 泥岩相, スランプ相, 泥岩相からなる.さらに, 粗 粒な堆積相は, 砂岩礫岩組相, 厚層砂岩組相, 礫岩 砂泥互層組相の堆積組相を構成する。砂岩礫岩組相 はAタイプ, B夕イプ, Cタイプに分けられる.

2 . 砂岩磼岩組相 $A$ タイプは upper channel 相, B夕イプは lower channel 相，Cタイプおよび厚
層砂岩組相は disributary channel 相，礫岩砂泥互 層組相は levee \& overbank deposits 相, 等量砂岩 泥岩相は sheet flow turbidite 相と解釈される。

3. 上小沢層のタービダイトは，中新世末から鮮新 世にかけて起こった構造運動によって形成された， 富倉背斜西翼のトラフと東翼のチャネル状トラフを 埋積して形成された。東翼の上小沢層は channelfill turbidite から，西翼は sheet flow turbidite か ら構成されている.

4. 西翼のタービダイトを構成する砕首物は主に水 内一小谷地域から，東翼の砕屑物は主に河東山地か ら供給された。

5 . 富倉地域は, 水内一小谷地域から東頝城地域に 連続するトラフと, 河東山地から流入するチャネル の会合地域である。

\section{謝 辞}

本研究を進めるにあたって，新潟大学理学部地質 科学教室の立石雅昭教授にはテーマ, 調査方法など 多方面にわたって御指導いただた。また新潟大学 理学部地質科学教室の小林嚴雄教授, 新潟大学教育 
学部の黒川勝己教授, 信州大学理学部地質学教室の 保柳康一博士，石油公団石油開発技術センターの高 野 修氏には御教示と御助言をいただいた。群馬県 立自然史博物館の野村正弘氏には有孔虫の鑑定をし ていただいた。ここに記して厚く感謝を表する次第 である。

\section{参考文献}

Bouma, A. H., 1962: Sedimentology of some flysch deposits. 168p., Elsevier Publs., Amsterdam.

遠藤正孝, 立石雅昭, 1990 ：北部フォッサ・マグナ, 中新世の 難波山海底扇状地の復元. 地質雑, 96, 193-209.

保柳康一・大上拓男, 1986a：海底チャネルによるタービダイト と関連粗粒岩の形成一中央北海道 - 中部中新統古丹別 層一. 地質雑，92，855-870.

五十嵐聡 - 高橋尚靖 - 大橋 克 $\cdot$ 喜多孝行 - 島津光夫,1984 : 新 潟，長野県境付近の津南一志賀地域の鮮新〜更新世の火 山岩類. 地質学論集, no. 24, 3-20.

黒川勝己 - 青木豊樹 - 伊藤貴彦, 1995 : 新井市南方富倉背斜地 域に扔ける火山灰鍵層とその対比一とくに土路層と菅沼 層 (八石油帯) との対比について一． 新大教育紀要， 36 , 99-157.

森島正夫，1941：信越国境富倉油田の層序．石油技協誌，9， 21-26.

Mutti, E., 1977: Distinctive thin-bedded turbidite facies and related depositional environments in the Eocene Hecho Group (South-central Pyrenees, Spain). Sedimentology, 24, 107-131.

Mutti, E. and Ricci-Lucchi, F., 1972: Turbidite of the
Northern Apennines: Introduction to facies analysis. International Geological Review, 20, 125-166.

中村和善, 1982 : 新潟県高田平野南方地域における後期新世代 の構造運動一その 1 堆積盆の変遷と基盤の運動像一。 地質雑，88，155-175.

新潟大学東䅡城地域地質調查グループ, 1987 : 新潟県東頚城地 域の中新～鮮新統の層序. 地球科学, 41, 165-168.

Saito, Y.,1962 :Geology of the Northern Part of the Fossa Magna. (Part 3). Jour. Fac. Ed. Shinshu Univ., 12, 134167.

高野 修, 1990 : 北部フォッサマグナ新第三系田麦川累層の卜 ラフ充填タービダイトの形成過程. 地質雑，96，1-17.

高野 修, 1992 : 北部フォッサ・マグナ地域の堆積盆埋積シス テムと堆積相規制要因に関する考察. 堆積学研究会 1992 年度秋季研究集会講演要旨集, 37-42.

竹内圭史, 1990 : 信越国境富倉背斜から産出した有孔虫化石. 日本地質学会第 97 年学術大会講演要旨, 61.

Tanaka, J., 1989: Sedimentary facies of the Cretaceous Izumi turbidite system, Southwest Japan. -An example of turbidite sedimentation in an elongated strike-slip tectonic basin-. Jour. Geol. Soc. Japan. 95, 119-128.

Underwood, M. B. and Bachman, S. B.,1982: Sedimentary facies association within subduction complexes. In Leggett, ed., Trench-Forearc geology, Geol. Soc. Spe. Pub., 537-550.

Walker, R. G. and Mutti, E.,1973: Turbidite facies and facies associations. In Turbidite and deep water sedimentation SEPM Pacific section short course Note. 119-237.

八木貞助 (1941) 上高井郡地質誌. 上高井教育会, $230 \mathrm{p}$.

\title{
新潟・長野県境富倉地域における中新〜鮮新統の堆積過程
}

\author{
中村 稔彦, 1999, 堆積学研究, No. 49, 23-39
}

Nakamura, T., 1999: Depositional processes of the Upper Miocene to Pliocene turbidites in the Tomikura area, located around the border of Niigata and Nagano Prefectures.

Jour. Sed. Soc. Japan, No. 49, 23-39

富倉地域に分布する下部鮮新統の上小沢層は, 中新世最末期から前期鮮新世にかけて起こっ た構造運動によって分化された NNE-SSW 方向に 2 本並走する富倉背斜西翼のトラフと背斜東 翼のチャネル状トラフを埋積したタービダイトである。背斜東翼のチャネル状トラフ内では構 造運動による基盤岩類の上昇によって, 南方の河東山地から砕屑物が供給された. 背斜西翼で は, 砕屑物がトラフ内の軸流によって, 調査地域南西方の水内地域から供給された。富倉地域 は水内地域から東澒城地域に連続する NNE-SSW 方向のトラフと, 南方の河東山地から流入す るチャネルの会合地域であった. 